\title{
How do Clubs of Alcoholics in Treatment Function? Differences Between the Perspectives of Members with Addiction and Family Members
}

\author{
Ana Opačić ${ }^{1}$, Tereza Oreb ${ }^{1}$, Katarina Radat ${ }^{2}$ \\ ${ }^{1}$ Faculty of Law University of Zagreb, Department of Social Work, Zagreb, Croatia, ${ }^{2}$ Soci- \\ ety for Social Support, Zagreb, Croatia
}

\begin{abstract}
Support groups for persons with alcohol addiction can be based on the self-help principle (AA model) or led by a professional, as is the case in Clubs of Alcoholics in Treatment (CAT). In the CAT model it is important to include the person with an addiction and close family members. In this quantitative research we compared these two perspectives to detect the differences in their views on the functioning of the support group. Research was conducted using stratified random sampling in 40 CATs in Croatia with 653 participants: 453 members with an addiction and 200 supporting or accompanying family members. Research instruments for assessing different aspects of CAT as a support group were developed by the authors. Data were analysed using MANOVA analysis to detect differences in the two perspectives. The results show that both groups demonstrate a significant level of satisfaction with different aspects of group work. However, MANOVA indicated the following differences: the accompanying family members are usually women, accompanying family members attend meetings less frequently and have lower insight into the professional's work, group relations and CAT's contribution to their personal development. The research is one of the rare empirical insights into CAT's functioning as a treatment group, with an attempt to distinguish heterogeneity in a membership. Since family members are somewhat more critical towards some features of CATs, in the future more emphasis should be placed on their active engagement in the group's processes.
\end{abstract}

Key words: alcoholism treatment, support group, family approach, family therapy, clubs of alcoholics in treatment.

Copyright @ 2019 KBCSM, Zagreb

e-mail: alcoholism.kbcsm@gmail.com•www.http://apr.kbcsm.hr

\section{Correspondence to:}

Ana Opačić

Phone:00385 14895801

Email: ana.opacic@pravo.hr

\section{Introduction}

By taking over many features of the Anonymous Alcoholics (AA), clubs of alcoholics in treatment (further in text: CAT) in Croatia, Italy and some other European countries have been developed in a slightly different form. CATs are communities of persons with alcohol addiction, where the meetings 
attend professional experts as well as family members [1]. CATs are nongovernmental organizations, their meetings are free of charge, available locally, on a weekly basis and are led by professionals (mainly psychiatrists, nurses, social workers or psychologists) who manage the group's process. There are approximately 12 families in a group [2], who participate in a wide range of activities in a community to enhance social integration, e.g. poetry nights, sport activities, publishing and art activities [3]. The main difference lies in the fact that AA does not have professional staff or leadership. They function on the principle of "members for members" [4], and therefore are not considered as professional treatment. Exceptionally, professionals may be involved in AA work in a counselling role [5], which can be traced to Torre's idea that CAT functions in a way that group members can participate in solving other members' problems [1].

The second significant distinction between AA and CAT is the spiritual component [6]. Frankl [7] found that people who cannot find meaning or purpose in life tend to abuse alcohol. Thus spirituality can be a key factor during the recovery process [8]. Krause's research [9] shows that people who find meaning in religion tend to avoid alcohol [10] and that spirituality helps in recovery $[11,12]$ and coping with feelings of guilt and shame [13]. The spiritual dimension is absent from the CAT, given that Vladimir Hudolin, MD on the occasion of its founding (1960s) contextualized CAT in a socialist society where religious influence was often shunned.

Comparing group therapy and individual psychotherapy, group treatment was found to be more effective for alcohol-dependent persons [14]. The largest number of people with the problem of excessive alcohol consumption attend AA meetings [15], and about 40-
$50 \%$ of active long-term members manage to maintain long-term abstinence [16]. Similar situation can be found in CAT where the majority of members $(66 \%)$ did not relapse during their participation (average membership duration is 4.68 years), while average abstinence period lasted around 5 years [3]. In AA, new members find a so-called sponsor who, by sharing his/her own alcoholism experience, helps during treatment [17] and creates a new social network available during crisis situations [18].

Alcohol-dependent persons in treatment maintain abstinence at a higher rate than people who did not undergo treatment $[5,19-$ 24]. Attending AA is one of the most important predictors of successful abstinence and sustained recovery from alcoholism, both in adults [14, 25, 26, 27, 28] as well as in adolescents [29], and is associated with a lower mortality rate, which is particularly significant for socially isolated persons [30]. Abstinence is an important therapeutic goal, even in people who had several relapses [31]. A study by Giuffredia et al. [14] involving AA's and CAT's members showed that psycho-medical-social treatment encourages abstinence with involvement of the patient's family in a varied community. The abstinence rate is higher compared to patients who underwent psychotherapeutic treatment at clinical centres. Also, abstinence rate is higher in addicts attending CAT than in those attending AA [14].

\section{The role of the group in recovery}

Given the lack of empirical data on the performance of CATs, most conclusions on group effects in alcoholism treatment refer to AA. The abstinence percentage is higher among people who attend group support meetings than in those who are only hospi- 
talized [14]. Significant factor associated with the recovery process is the inclusion in a new social network [32]. One of the major benefits of attending AA meetings is the change of social network [33, 34], as AA members replace their alcohol-consuming friends with new friends who do not consume it [34].

Several researches [24] show that the presence of "sober" social support is in a positive correlation with better treatment outcome. Such treatment groups are trying to create a surrounding where members can view and accept themselves as alcohol-dependent persons, followed by creating new friendships [24, 32, 35]. Weisner et al. [24] state that despite attending AA meetings, the development of a sober social network is a critical part of the process. One of the AA mechanisms of action brings positive changes in friendships $[24,36]$ and social networks of alcohol dependent persons [24, 34].

Attending AA meetings turned out to be useful for extroverted, socially oriented individuals who fulfilled their need for socializing and sharing experience at these meetings [23, $26,28,37]$, but also for those with depression, which is a common cause of alcoholism [38]. The group provides an emphatic and welcoming environment where members can discuss and express themselves [5], and connect with others in small, intimate groups [39]. Additionally, by helping others, members in such groups also help themselves, as this increases their commitment to recovery, perception of importance to others, social status, and feeling of independence [40, 41].

Young people involved in the 12-Step group evaluate participation in the group through the ability to learn from others [42]. If a member realizes that the group program has helped others, he/she will begin to understand that the program can also help him/her
[4]. New members are more likely to accept advice based on previous experience of other members [34]. Participation in the group develops a mutual relationship, common goals and values [43], reciprocal acceptance and giving [5], nourishes hope and catharsis [44]. The group is a place where members can develop and practice social skills [4], learn coping skills and exchange experiential knowledge and information [45], reduce interpersonal insecurity [46], change the existing dysfunctional attitudes [47], understand themselves better [39], increase their sense of well-being [35], and improve their overall psychological functioning [36]. These are all important elements for maintaining abstinence. Also, participation in a support group maintains or increases the motivation for recovery [4]. When starting abstinence, there is a need for structure and support that is provided with this kind of organized treatment $[23,26,28]$. Generally, the psychosocial support of AA members has the most important role in this program $[48,49]$.

\section{Importance of family participation and treatment}

Addictive behavior should be considered in the context of family functioning, the environment and the society in general [50]. In North America, there are separate support groups (Al-Anon) for family members [51], while alcohol-dependent persons in the CAT are usually accompanied by a family member, [52] usually, by a spouse or a partner. In Croatian CATs, $63 \%$ of members have someone's support upon arrival, mostly from a spouse $(80.7 \%)$, a child $(4.1 \%)$, parents $(7.1 \%)$, siblings $(5.1 \%)$ or friends $(2.5 \%)$ [3]. Family members' involvement in the treatment is important for maintaining abstinence, but also for the family in general, given that alcohol 
dependence is viewed and treated as a family disease [53]. Several authors wrote about co-dependency [50, 54] of family members who develop a pathological addiction - excessive involvement and continuous care for the family member who drinks, hiding it from others because of the feeling of shame [53]. For this reason, participation of family members is extremely important in order to improve lifestyle, interpersonal communication and family dynamics.

Family support is proven to be important for the recovery of alcohol dependency [55]. Hence, maintaining abstinence is more difficult for members who are single. Research shows that people with poor social support are abstinent for a shorter time $[56,57]$ as the involvement of family members is one of the most important factors of recovery [16], especially for men who are supported by their wives [58]. However, some researches show different results, indicating that abstinence is not compromised by the absence of adequate social support [59].

Considering the fact that CAT integrates both members with addiction problem and one supporting (usually family) member, the aim of this research was to analyse the key differences in evaluating some dimensions of CATs as a support treatment group.

\section{Subjects and methods}

The study was conducted using stratified random sampling in 40 CATs in Croatia. The questionnaires were filled out during group meeting. Prior to conducting research, the research team obtained an approval from the Croatian Association of Clubs of Alcoholics in Treatment; afterwards professionals in each CAT were contacted to set up a date for conducting the questionnaire. The research- ers followed the essential ethical standards in obtaining informed consent from the participant and ensuring anonymity and confidentiality. The participants were informed that their participation was on a voluntary basis and that they had the right to stop filling the questionnaire at any time.

\section{Participants}

In this research there were in total 653 participants, 453 (69\%) were members in alcoholism treatment, and 200 (31\%) their accompanying person, usually a partner or parent. There were 406 male participants (62\%) and 229 female participants $(35 \%)$. On average participants were members of the CAT for 4.72 year $(M=4.72, S D=5.192)$, with $26 \%$ participants $(\mathrm{N}=161)$ in the CAT up to one year, and 28\% members for more than 5 years $(\mathrm{N}=178)$. Participants attended club meetings on average once in two weeks $(\mathrm{M}=$ $1.49, \mathrm{SD}=0.93)$. However, the vast majority of participants, or $70 \%$, attended every week $(\mathrm{N}=460), 19 \%$ once in two weeks $(\mathrm{N}=121)$, $6 \%$ once a month $(\mathrm{N}=36)$, and $5 \%$ only several times a year $(\mathrm{N}=35)$. When it comes to participation in community activities organised by the CAT, the participants were divided, $343(55 \%)$ were active, and 280 (45\%) inactive.

\section{Measures}

The research instrument was designed by the authors for the purpose of this research. It consisted of questionnaires with composite average values in Table 1.

1. A short questionnaire for assessing the $b a$ sic features of the member's functioning in CAT: gender, duration of membership, frequency of attending CAT, participation in outgroup activities. 
Table 1. Descriptive statistics for cumulative results regarding some aspects of CAT as a support group

\begin{tabular}{|c|c|c|c|c|}
\hline Variables & $\mathrm{N}$ & Min. & Max. & $\mathrm{M} \pm \mathrm{SD}$ \\
\hline $\begin{array}{l}\text { Assessment of CAT contribution to progress in various } \\
\text { life aspects }\end{array}$ & 625 & 1.00 & 5.00 & $4.18 \pm 0.765$ \\
\hline $\begin{array}{l}\text { CAT's contribution to changes in psychosocial function- } \\
\text { ing }\end{array}$ & 610 & 1.09 & 5.00 & $4.07 \pm 0.745$ \\
\hline Other members' relations towards an individual & 612 & 2.00 & 5.00 & $4.27 \pm 0.598$ \\
\hline Personal relationship between experts and users & 615 & 2.86 & 5.00 & $4.56 \pm 0.468$ \\
\hline $\begin{array}{l}\text { Level of understanding between users and professional } \\
\text { staff }\end{array}$ & 614 & 1.00 & 5.00 & $4.57 \pm 0.586$ \\
\hline $\begin{array}{l}\text { Assessment of satisfaction with the basic features of } \\
\text { CAT as a support group. }\end{array}$ & 632 & 2.33 & 5.00 & $4.61 \pm 0.468$ \\
\hline $\begin{array}{l}\text { Assessment of satisfaction with the status of CAT as an } \\
\text { organization }\end{array}$ & 626 & 1.00 & 5.00 & $3.92 \pm 0.727$ \\
\hline
\end{tabular}

2. Questionnaire for assessment of CAT contribution to progress in various life aspects with 8 items on an interval scale (1-5), including improvements in partnership interactions, parenthood skills, self-image, more efficient dealing with life challenges, communication skills, developing desired behavioral change, building self- confidence and developing oneself as s successful person. The overall score was calculated as the mean value. Cronbach $\alpha$ was 0.93 , indicating good reliability. The scale had a one factor structure, explaining $64.48 \%$ of variance.

3. Questionnaire for assessment of CAT contribution to changes in psychosocial functioning with 11 items (Cronbach $\alpha=0.93$.) The total score was calculated as the mean value on the interval scale (1-5) covering levels of psychosocial change: cognitive change (e.g. Attending Club meetings helped me to understand myself better), emotional change (e.g. Attending Club enables me to express my feelings.) and behavioral change (e.g. Arrivals at the Club encouraged me to make an impact on my environment). Scale has a one factor structure, explaining $59.37 \%$ of variance.

4. Questionnaire for assessment of other members' relations towards an individual with 9 items (Cronbach $\alpha=0.87$ ). The exemplar items were: I feel that I belong in this Club.; Other members don't judge me even if I do something that they do not approve. The total score was calculated as the mean value on an interval scale (1-5). The scale had a one factor structure explaining $51.41 \%$ of variance.

5. Questionnaire for assessment of professional staff's relation towards members with 9 items. Factor analysis with Varimax rotation indicated a two-factor structure (explaining all together $55.53 \%$ of variance). The first factor refers to the personal relationship 
between experts and users. The personal relationship includes level of support, equality and respect (eg. Professional worker shows that he/she cares about my well-being) (7 items, $\Lambda=3.91$, explaining $43.43 \%$ of variance, Cronbach $\alpha=0.78)$. The second factor refers to the level of understanding between the users and professional staff (e.g. "Practitioner and I agree on ways of achieving bigh quality of abstinence"), ( 2 items, $\Lambda=$ 1.09 , it explains $12.10 \%$ of the variance, Cronbach $\alpha=0.79)$. The total score for each factor was calculated as the mean value on an interval scale (1-5).

6. Scale for assessment of satisfaction with CAT with 8 items (scale 1 to 5) has a two - factor structure obtained with the included Varimax rotation, explaining the total of $60.71 \%$ of variance. The first factor relates to the assessment of the satisfaction with the basic features of the CAT as a support group covering group relations, the professional's approach, expertise and work methods ( 4 items, $\Lambda=3.47$, explains $43.38 \%$ of the variance, Cronbach $\alpha=$ $0.78)$. The second factor refers to the assessment of satisfaction with the CAT's status as an organization, including status compared to other clubs, the status in the wider community, member's involvement and out-group activities (4 items, $\Lambda$ $=1.39$; explains $17.32 \%$ of the variance, Cronbach $\alpha=0.75)$. The total score for each factor was calculated as the mean value on an interval scale (1-5).

Statistical analyses

In order to define the key differences among members with addiction and the accompanying persons in their perspectives towards some dimensions of CAT as a support group, MANOVA was used and per- formed in program SPSS 20.0. A fixed factor was variable participant's status in the club, meaning 1) a member with alcoholism addiction and 2) an accompanying person. The dependent variables were: a) gender, b) duration of membership in CAT, c) frequency of attending CAT meetings, d) participation in out-group activities, e) assessed CAT contribution to the progress in various life aspects, f) assessed CAT contribution to changes in psychosocial functioning, g) other members' relations towards the individual, h) personal relationship between an expert and a member (level of understanding between a member and an expert), satisfaction with the basic features of CAT as a support group, k) satisfaction with the status of CAT as an organization.

\section{Results}

The MANOVA analysis indicated a group of variables that differentiate the most the two groups of CAT members: members with an addiction problem $(\mathrm{N}=364,71 \%)$ and members who are accompanying persons $(\mathrm{N}=152,29 \%)$. In the final analysis 516 participants remained. Due to the unbalanced group size, two variables did not meet the criterion of Levene's homogeneity test (Table 2). However, we decided to keep them in the analysis, counting on MANOVA robustness for this criterion [60].

The two groups of CAT members differ significantly with this set of dependent variables (Table 3).

In the final model, variables that significantly distinguish the two groups of CAT members are: gender, frequency of attending CAT meetings, assessed contribution of CAT to progress in various life aspects, other members' relations towards an individual, 
Table 2. Levene's Test of Equality of Error Variances

\begin{tabular}{lcccc}
\hline Variables & F & df1 & df2 & p \\
\hline Gender & 1.109 & 1 & 514 & 0.293 \\
Length of membership in CAT & 1.878 & 1 & 514 & 0.171 \\
$\begin{array}{l}\text { Frequency of attending CAT meetings } \\
\text { Participation in out-group activities }\end{array}$ & 64.472 & 1 & 514 & 0.000 \\
$\begin{array}{l}\text { Assessed CAT's contribution to progress in various life as- } \\
\text { pects }\end{array}$ & 0.206 & 1 & 514 & 0.650 \\
$\begin{array}{l}\text { Assessed CAT's contribution to changes in psychosocial } \\
\text { functioning }\end{array}$ & 1.215 & 1 & 514 & 0.271 \\
$\begin{array}{l}\text { Other members' relations towards an individual } \\
\text { Personal relationship between expert and member }\end{array}$ & 0.134 & 1 & 514 & 0.715 \\
$\begin{array}{l}\text { Level of understanding between member and an expert } \\
\text { Satisfaction with the basic features of CAT as a support }\end{array}$ & 0.6295 & 1 & 514 & 0.109 \\
group & & 1 & 514 & 0.588 \\
Satisfaction with the status of CAT as an organization & 2.325 & 1 & 514 & 0.431 \\
\hline
\end{tabular}

personal relationship between the expert and member, satisfaction with the basic features of CAT as a support group and satisfaction with the status of CAT as an organization (Table 4).

As expected, members with an addiction problem were usually male, while accompanying persons were usually female. Members with an addiction problem attended meetings more often (once a week) and their rates were higher in every other assessed aspect, i.e. they were more satisfied with different aspects of CAT functioning: other members' relations towards an individual, personal relationship between expert and member, satisfaction with the basic features of the CAT as a support group and satisfaction with status of the CAT as an organization, and they assessed higher contribution of CAT to progress in various life aspects. It is also important to notice that both groups rated with highest scores the professional workers, while group relations were rated somewhat

Table 3. Box M value for equality of covariances, F ratio and Partial Eta Square for two different membership statuses in CTA

\begin{tabular}{lcccc}
\hline $\begin{array}{l}\text { Box } \mathrm{M} \text { value for equality of } \\
\text { covariances }\end{array}$ & $\begin{array}{c}\mathrm{F} \\
\text { (Wilks lambda) }\end{array}$ & Error df & p & $\begin{array}{c}\text { Partial } \\
\text { Eta Square }\end{array}$ \\
\hline $\begin{array}{l}\text { Box's } \mathrm{M}=154.67 \\
\mathrm{p}=0.000\end{array}$ & 31.51 & 504 & 0.000 & 0.407 \\
\hline
\end{tabular}




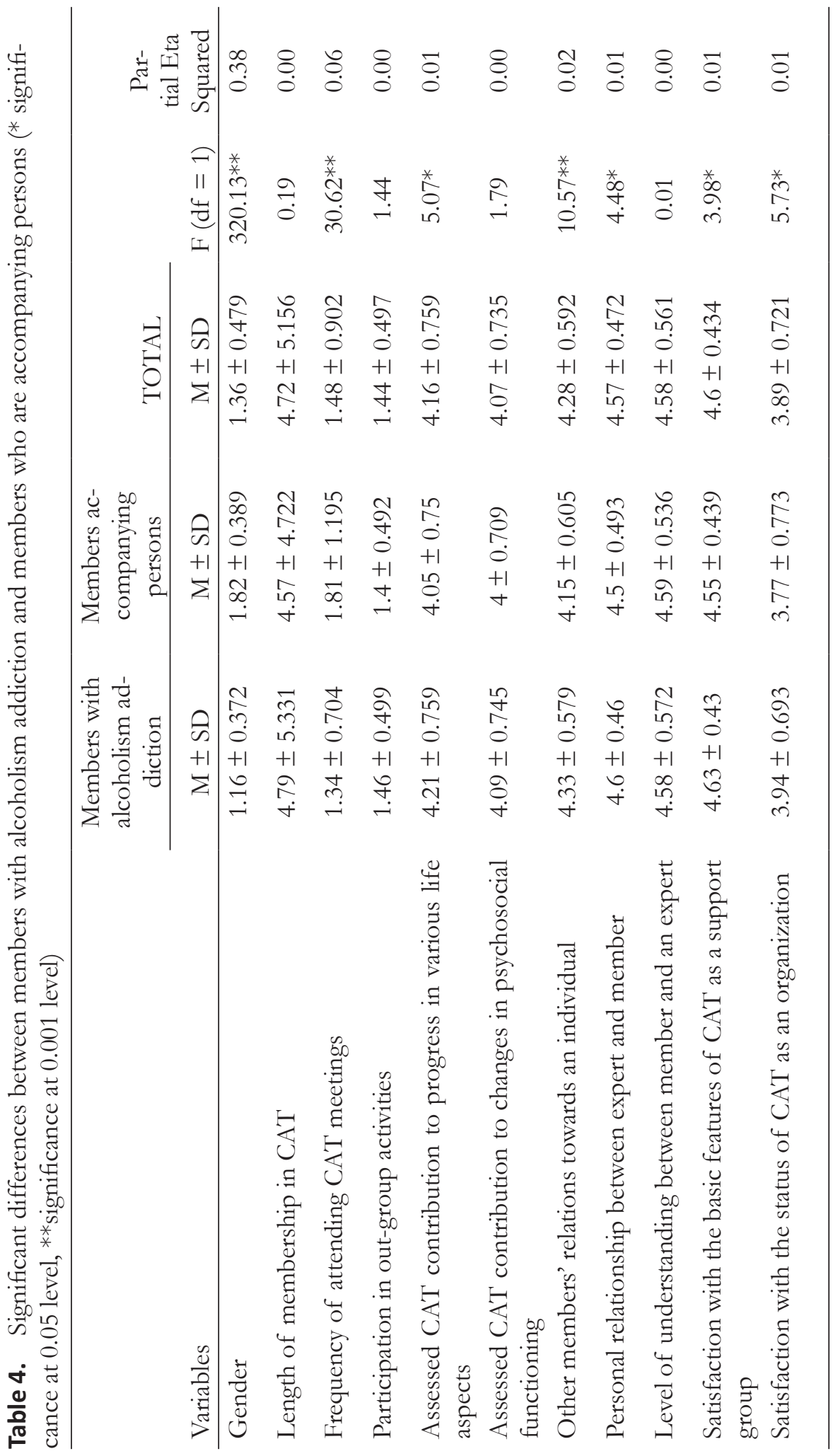


lower. The lowest rates were given for satisfaction with functioning of CAT as an organization. There is still room for raising the status of CAT within the community, promoting more community based activities and advocating their sustainable development.

\section{Discussion}

The current researches demonstrate that group treatment significantly impacts both abstinence $[3,14,16]$ and personal development $[3,4,46]$ of the members. The group is a healing environment that enables mutual support and self-expression [5] while an important therapeutic aspect for the member is the building of a new social network [34, 36]. Due to the idea that alcoholism somehow leads towards co-dependency among family members [50, 54], including a family member in the treatment is of critical importance. This is strongly promoted in CAT practice and our view is that family members aren't merely observers and supporters, but are committed to their own personal recovery and change as well. In this research we wanted to compare these two perspectives in treatment groups. We found the expected differences in terms of gender (accompanying family members were usually women, while alcoholism remains a predominantly male problem), on average the accompanying persons attended meetings less frequently and were more critical of some aspects of the group. The accompanying persons rated lower the contribution of CAT to their personal progress, which is understandable since they were not in the direct focus of the group. They were also somewhat more critical when it came to their relation with an expert, general satisfaction with the club and other members' relation toward them. However, both members with an addiction and accompanying members recognized that CAT significantly contributed to their own personal progress and psychosocial change in terms of more adequate cognitive, behavioral and emotional functioning. Their rating also indicated that CATs are healing communities that nurture respectful group relations among the members, a personal relation between an expert and members, as well as mutual understanding of alcoholism. CATs are strongly cohesive communities where both member groups are satisfied with its dynamic. This is also visible in the fact that the average duration of membership is more than 4 years, with no differences among members with addiction and accompanying members. At the beginning of the treatment the accompanying members usually indicate whether they will participate in CAT activities or not. The researched participants found themselves within a group context but when it came to supporting CAT as an organization or participating in community based activities, they remained divided, with no differences between the two members' groups.

We must point out that the results of this research could be biased due to the fact that only active CAT members participated in the survey and we did not invest additional effort to reach those members who were absent from the meeting when the survey was conducted. Also, high correlations (higher than 0.4) between different variables of group dynamics could be a result of the same bias and general positive orientation towards CAT. Providing more time and personal space when filling the questionnaire, instead of conducting a group survey, could eliminate this limitation and secure more variability among the participants. 
We find this research helpful for further development of group practice in alcoholism treatment. Family members are expected to support the treatment, but their perspective lacks in knowledge of empirical studies. Thus, it was important to include both perspectives as equally important, but also to improve the empirical insights in group dynamics different from AA practice. The research participants' perspectives differ in some aspects, but in general their perception of group dynamics and the professionals' work

\section{References}

1. Torre R. Oporavak alkoholičara u klubovima liječenih alkoholičara. Zagreb: Hrvatski savez klubova liječenih alkoholičara; 2006.

2. Breitenfeld, D, Wölfl, D. Alkoholizam: sprječavanje, liječenje, oporavak: PIPA. Rijeka: Personal publishing; 2010.

3. Opačić A, Oreb T, Radat K. Characteristics and significance of professional-led support groups in the treatment of alcoholism. Alcohol Treat Q 2017;35:359-371.

4. Schneider SV. Trauma and 12-step recovery. Journal of Chemical Dependency Treatment 2006;8:163-186.

5. Kelly JF, Yeterian JD. Mutual-help groups for dually diagnosed individuals: Rationale, description, and review of the evidence. J Groups Addict Recover 2008;3:217-242.

6. Gross M. Alcoholics Anonymous: Still sober after 75 years. Am J Public Health, 2010;100:2361-2363.

7. Frankl V: Psychotherapy and existentialism. New York: Washington Square Press; 1967.

8. Brown S. Treating the alcoholic: A developmental model of recovery. New York: John Wiley \& Sons; 1985.

9. Krause N. Race, religion, and abstinence from alcohol in late life. J Aging Health 2003;15:508-533. is quite positive, and clubs for treated alcoholics are recognised as important not only for maintaining abstinence, but for reaching higher quality of sober life.

\section{Acknowledgments}

None.

\section{Conflict of interest}

None to declare.
10. Stewart C, Koeske G, Pringle JL. Religiosity as a predictor of successful post-treatment abstinence for African-American clients. J Soc Work Pract Addict 2007;7:75-92.

11. Kurtz E, Ketcham K. The spirituality of imperfection. New York: BantamBooks; 1992.

12. Van der Walde H, Urgenson FT, Welz SH, Hanna FJ. Women and alcoholism: A biopsychosocial perspective and treatment approaches. J Couns Dev 2002;80:145-153.

13. Kurtz E. Shame and Guilt: Characteristics of the dependency cycle. Minneapolis: Hazelden Press; 1981

14. Giuffredi C, di Gennaro C, Montanari A, Barilli A, Vescovi PP. Alcohol addiction: evaluation of alcohol abstinence after a year of psycho-medicalsocial treatment. Addic Biol 2003;8:219-228.

15. Room R, Greenfield T. Alcoholics anonymous, other 12-step movements and psychotherapy in the US population, 1990. Addiction 1993;88:555562.

16. Grinspoon L. Treatment of alcoholism. Harv Ment Health Lett 2000;13:1-5.

17. Sharma M, Branscum P. Is Alcoholics Anonymous effective? J Alcohol Drug Educ 2010;54:3-6.

18. Kelly JF, Myers MG. Adolescents' participation in Alcoholics Anonymous and Narcotics Anony- 
mous: Review, implications and future directions. J Psychoactive Drugs 2007;39:259-269.

19. Kennedy BP, Minami M. The Beech Hill Hospital/Outward Bound Adolescent Chemical Dependency Treatment Program. J Subst Abuse Treat 1993;10:395-406.

20. Hsieh S, Hoffmann NG, Hollister DC. The relationship between pre-, during-, post-treatment factors, and adolescent substance abuse behaviors. Addict Behav 1998;23:477-488.

21. Fiorentine R. After drug treatment: Are 12-step programs effective in maintaining abstinence? Am J Drug Alcohol Ab 1999;25:93-116.

22. Kelly JF, Myers MG, Brown SA. A multivariate process model of adolescent 12-Step attendance and substance abuse outcome following inpatient treatment. Psychol Addict Behav, 2000;14:376389.

23. Vaillant GE. A 60-year follow-up of alcoholic men. Addiction 2003;98:1043-1051.

24. Weisner C, Matzger H, Kaskutas LA. How important is treatment? One-year outcomes of treated and untreated alcohol-dependent individuals. Addiction 2003;98:901-911.

25. Bischof G, Rumpf HJ, Hapke U, Meyer C, John $\mathrm{U}$. Maintenance factors of recovery from alcohol dependence in treated and untreated individuals. Alcohol Clin Exp Res 2000;24:1773-1777.

26. Bond, J, Kaskutas, LA, Weisner C. The persistent influence of social networks and alcoholics anonymous on abstinence. J Stud Alcohol 2003;64:579588.

27. Kaskutas LA. Alcoholics Anonymous effectiveness: Faith meets science. J Addic Dis 2009;25:145157.

28. Krentzman AR, Robinson EAR, Perron BE, Cranford JA. Predictors of membership in Alcoholics Anonymous in a sample of successfully remitted alcoholics. J Psychoactive Drugs 2011;43:20-26.

29. Monti PM. 12-Step affiliation helps teens maintain long-term alcohol abstinence. Brown Univ Dig Addict Theory Appl 2009;28:1-8.

30. Masudomi I, Isse K, Uchiyama M, Watanabe H. Self-help groups reduce mortality risk: A 5-year follow-up study of alcoholics in the Tokyo metropolitan area. Psychiat Clin Neuros 2004;58:551557.
31. Mann K, Schafer DR, Langle G, Ackermann K, Croissant B. The long-term course of alcoholism, 5, 10 and 16 years after treatment. Addiction 2005;100:797-805.

32. Wismer Bowden J: Recovery from alcoholism. A spiritual journey. Issues Ment Health N 1998;19:337-352.

33. Humphreys K. Professional interventions that facilitate 12-step self-help group involvement. Alcohol Res Health, 1999;23:93-108.

34. Kaskutas LA, Bond J, Humphreys K. Social networks as mediators of the effect of Alcoholics Anonymous. Addiction 2002;97:891-900.

35. Kairouz S, Dubé L. Abstinence and well-being among members of Alcoholics Anonymous: Personal experience and social perception. The Journal of Social Psychology 2000;140:565-579.

36. Humphreys K, Moos RH, Cohen C. Social and community resources and long-term recovery from treated and untreated alcoholism. J Stud Alcohol. 1997;58:231-238.

37. Morgenstern, J., Langenbucher, J., Labouvie, E., Miller, K. J. The comorbidity of alcoholism and personality disorders in a clinical population: prevalence rates and relation to alcohol typology variables. J Abnorm Psychol. 1997;106:74-84.

38. Peters TJ, Millward LM, Foster J. Quality of life in alcohol misuse: comparison of men and women. Arch Women Ment Hlth. 2003;6:239-243.

39. Demirbaş H, Doğan BY, Özgür İlhan İ. The relationship between the group therapeutic factors and relapse in alcohol dependent inpatients. Düşünen Adam. 2012;25:119-124.

40. Zemore SE, Kaskutas LA, Ammon LA. In 12 step groups, helping helps the helper. Addiction 2004;99:1015-1023.

41. Pagano ME, Friend KB, Tonigan JS, Stout RL. Helping other alcoholics in Alcoholics Anonymous and drinking outcomes: Findings from Project MATCH. J Stud Alcohol. 2004;65:766-773.

42. Dadich A. Expanding our understanding of selfhelp support groups for substance use issues. J Drug Educ. 2010;40:189-202.

43. Stead P, Viders J. A "Sharp" approach to treating alcoholism. Soc Work 1979;24:144-149.

44. Kelly JF, Myers MC, Rodolico J. What do adolescents exposed to Alcoholics Anonymous think 
about 12-step groups? J Subst Abuse. 2008;29:5362.

45. Klemenčić Rozman MM. Differences in the perceived benefits of membership among types of self-help and support groups. Ljetop Soc Rada. 2015;22:351-370.

46. Suire JG, Bothwell RK. Study highlights psychosocial benefits of Alcoholics Anonymous. Am J Addict, 2006;15:252-255.

47. Chai S, Cho Y. Cognitions associated with recovery from alcohol dependence. Jpn Psychol Res 2011;53:327-332.

48. Barrick C, Connors GJ. Relapse prevention and maintaining abstinence in older adults with alcohol-use disorders. Drugs Aging 2002;19:583-594.

49. Zafiridis P, Lainas S. Alcoholics and narcotics anonymous: A radical movement under threat. Addict Res Theory. 2012;20:93-104.

50. Allamani A. Views and models about addiction: Differences between treatments for alcohol-dependent people and for illicit drug consumers in Italy. Subst Use Misuse. 2008;43:1704-1728.

51. Al-Anon Family Groups: How Al-Anon/Alateen works for me. Retrieved from http://www.alanon.org/how-al-anon-works-for-me, 2017.

52. Hudolin V. Alkohologija. Zagreb: Institut za proučavanje i suzbijanje alkoholizma i drugih narkomanija; 1972.
53. Torre R. Alkoholizam: prijetnja i oporavak. Zagreb: Profil; 2015.

54. Beattie, M. Codependent no more: How to stop controlling others and start caring for yourself. Center City, Minnesota: Hazelden; 1986.

55. Terra MB, Barros HM, Stein AT, Figueira I, Athayde LD, Ott DR et al. Predictors of relapse in 300 Brazilian alcoholic patients: A 6-month follow-up study. Subst Use Misuse. 2008;43:403-411.

56. Monahan SC, Finney JW. Explaining abstinence rates following treatment for alcohol abuse: a quantitative synthesis of patient, research design and treatment effects. Addiction 1996;91:787-805.

57. Bargiel-Matusiewicz K, Ziebaczewska M. The influence of social support on the occurrence of the withdrawal syndrome in alcohol abused patients. J Physiol Pharmacol. 2006;57:23-31.

58. Trotter AB, Gozali J, Cunningham LJ. Family participation in the treatment of alcoholism. T Pers Guid J. 1969;48:140-143.

59. Saxena PP, Mital AK. Predictive value of depression and social support with respect to alcohol abstinence. Indian J Psychol Med. 2011;33:115-118.

60. Bray JH, Maxwell SE. Multivariate analysis of variance. London: Sage publications; 1985.

\section{Kako funkcioniraju klubovi liječenih alkoholičara? Razlike u perspektivama članova s problemom ovisnosti i članova njihovih obitelji}

Sažetak- Grupe podrške za osobe s problemom ovisnosti o alkoholu mogu biti temeljene na načelu samopomoći (AA grupe) ili mogu biti stručno vođene kao što je slučaj s klubovima liječenih alkoholičara (KLA). U modelu klubova liječenih alkoholičara važno je istovremeno uključiti članove s problemom ovisnosti i članove njihovih obitelji. U ovom kvantitativnom istraživanju usporedili smo ove dvije perspektive kako bi detektirali razlike u njihovom viđenju KLA kao tretmanske grupe. Istraživanje je provedeno na stratificiranom slučajnom uzorku od 40 KLA u Hrvatskoj sa ukupno 653 sudionika: 453 članova liječenih od ovisnosti o alkoholu i 200 članova koji dolaze kao podrška. Instrumentarij za procjenu različitih aspekata KLA kao grupe podrške razvili su autori istraživanja. Podaci su analizirani MANOVA analizom kojom se utvrđuju razlike između dvije grupe sudionika. Rezultati pokazuju da obje grupe iskazuju zadovoljstvo različitim aspektima grupnog rada. Međutim, MANOVA analiza ukazala je na sljedeće statistički značajne razlike: članovi koji dolaze kao podrška uglavnom su žene, u prosjeku dolaze rjeđe na grupne sastanke te imaju nešto niže procjene rada stručnjaka, 
odnosa u grupi i doživljenog doprinosa KLA njihovom osobnom razvoju. Istraživanje pruža jedno od rijetkih empirijskih uvida u funkcioniranje KLA kao tretmanske grupe s pokušajem da se dobije uvid u heterogenost članstva. S obzirom da su članovi koji dolaze kao podrška nešto kritičniji prema radu KLA, u daljnjoj praksi bi trebalo staviti više naglaska na njihovo aktivno uključivanje u grupne procese.

Ključne riječi: tretman alkoholizma, grupe podrške, obiteljski pristup, klubovi liječenih alkoholičara 